\title{
Violent repression of environmental protests
}

Helen M. Poulos ${ }^{1 *}$ (D) and Mary Alice Haddad²

\begin{abstract}
As global sea levels and natural resource demands rise, people around the world are increasingly protesting environmental threats to their lives and livelihoods. What are the conditions under which these peaceful environmental protests are violently repressed? This paper uses the random forest algorithm to conduct an event analysis of grassroots environmental protests around the world. Utilizing a database of 175 grassroots environmental protests, we found that: (1) a large proportion (37\%) of the protests involved violent repression; (2) most of the violence (56\%) was directed against marginalized groups; and (3) violence was geographically concentrated the global south in Latin America and Asia. The primary predictors of violence were political empowerment, GDP per capita, industry type, the presence of marginalized groups, and geographic region. Our analysis reveals a complex relationship between governance, resource extraction, and international funding that often resulted in human rights violations against marginalized groups.
\end{abstract}

\section{Background}

Grassroots environmental protests represent a key mechanism for local populations to resist the negative effects of anthropogenic environmental hazards. However, these peaceful protests are sometimes repressed using violent means. The goal of this article is to identify the conditions under which peaceful environmental protests are more likely to be violently repressed and generate policy recommendations that could reduce or eliminate that violence.

Previous research has identified a number of factors related to the identity of the protesters, the content and duration of the protest, and its socio-political context that can affect the probability of violent repression. Numerous studies about Not In My Back Yard (NIMBY) politics have found that states and corporations commonly target vulnerable communities as site locations for environmentally hazardous projects, so those types of communities are more likely to be engaged in environmental protests and more likely to be violently repressed than betterresourced communities in the same countries (Adeola

\footnotetext{
*Correspondence: hpoulos@wesleyan.edu

${ }^{1}$ College of the Environment, Wesleyan University, 284 High St., Middletown, CT 06451, USA

Full list of author information is available at the end of the article
}

2000; McGurty 1997; Rabe 1994; Roberts and Ash 2009). Scholars have also found that extractive industry projects are more often associated with violent repression than other types of industries (Downey et al. 2010; Blanton and Blanton 2009). Researchers have found when the two factors combine, when communities containing marginalized groups (defined herein as ethnic minorities or economically disadvantaged groups) protest natural resource extraction, they are particularly likely to be violently repressed (Koopmans and Rucht 2002; Bernauer et al. 2012; Homer-Dixon 1994). Scholars have also found that protest duration (Box-Steffensmeier et al. 2003) and the presence of documented human health hazards on site (Zheng and Liu 2013; Fagin 2013) can influence the likelihood of violent repression. Some scholars have found that violent repression of peaceful protests is more common in poor, authoritarian states that lack adequate legal protections than it is in rich, democratic countries with robust legal systems (Poe et al. 1999; Weede 1987; Besley and Persson 2011).

Thus far, research on violent repression of peaceful environmental protests has commonly used a case study methodology, which can help develop theories about the conditions that might result in violence against peaceful protesters, but cannot test those theories (Adeola 2000;

\section{黑 Springer}


Roberts and Ash 2009; Downey et al. 2010). Large-n research about violent repression has tended to analyze conflicts at the national level rather than local conflicts. While it is sometimes the case that grassroots environmental protests can transform into or combine with regime-threatening social movements (Haddad 2014), that outcome is unusual; locally-focused protests are much more common. Event analysis focusing on grassroots environmental protests has the potential to explain the interaction of subnational, national, and international factors related to the violent repression of peaceful protests (Bond et al. 2003; Box-Steffensmeier and Zorn 2002; Koopmans and Rucht 2002).

No prior research has employed a large-n statistical analysis to identify which factors and factor combinations are the most important in determining the likelihood that a grassroots environmental protest will be violently repressed. We employ the random forest algorithm using a suite of key violent repression predictor variables from the literature to examine the mechanisms underscoring violent repression in grassroots environmental protests using a database of environmental protests from around the world. We then use those results to develop a series of policy recommendations intended to reduce the rate and intensity of violence directed toward peaceful protesters.

\section{Methods}

\section{Environmental protest database}

To investigate the factors influencing violent outcomes in environmental protests, we compiled a global database of 175 grassroots environmental protest cases from a pool of 35,472 periodical publication search results from 1965 to 2013 using the Lexis-Nexis Academic (www.lexisnexis.com) and Factiva (http://global.factiva.com) media databases. Factiva continuously archives periodical data from more than 32,000 sources from nearly every country worldwide in 28 languages, including over 450 continuously updated newswires (sources can be accessed here: http://www.proquest.com/documents/Title_List_Factiva.html?docID=242334851). Lexis-Nexis continuously archives news information from over 10,000 media sources (sources listed here: http://amdev.net/rpt_download.php). Together, they represent the most comprehensive databases of media coverage available. Media publications are useful because they provide information about large numbers of events and they are well-known for documenting social movement dynamics (Earl et al. 2004). While such event data can suffer from coverage bias (Ortiz et al. 2005; Barranco and Wisler 1999), they remain one of the only sources of data on protest events. To minimize biases and accuracy issues resulting from our use of a media-derived dataset, we: (1) searched for articles using multiple media database archives, (2) only included cases that were covered by more than one media source, and (3) confirmed and supplemented the information reported in the articles using ancillary information obtained through online sources (i.e. a series of web searches using Google to confirm separately that the event happened and to identify additional details about each protest event that were coded in the database as listed in Table 1). Ancillary data searches were performed as a means for completely coding the database because not all information in the database was directly stated in the short newspaper articles. If we could not find complete information to code the case completely in the database, we did not include the case in the study. Information coded using web information was included only if it was reported in more than one online search result. This case search methodology likely overlooked some environmental protest events that were suppressed by local governments and not reported by newspapers. For example, our sample size in the Middle East was quite low, probably because of poor reporting of protest events. Yet, even working within those limitations, the two databases we selected have the best world coverage of news events available, and they likely provided a representative sample of violent repression of grassroots environmental protests at regional- and global-scales.

We searched Lexis-Nexis and Factiva databases for a series of keywords associated with grassroots environmental protest based on a topic search of the environmental politics literature (Snow et al. 2008; Fillieule and Jiménez 2003; Dalton et al. 2003; Koopmans and Rucht 2002), which returned a total of 35,472 articles, which we scanned individually for grassroots environmental protest event data to build the final 175 case database. Search terms included: 'grassroots environmental protest' and the word 'protest' in conjunction with the terms 'nuclear,' 'pollution', 'conservation', 'environmental', 'wildlife preserve, 'toxic waste,' 'land fill, 'mining,' 'dam,' 'hydroelectric', and 'wind energy'. Protests were excluded from the study if they (1) failed to demonstrate evidence of locally-generated activism (i.e. grassroots), (2) lacked sufficient qualitative information about protest characteristics, or (3) appeared in fewer than two newspaper articles. Cases were then categorized into two groups: protests that remained nonviolent throughout and cases where some form of violence against activists occurred. Violence included any form of injury ranging from beatings to death.

The potential explanatory variables included in this study were chosen based on their prevalence in the newspaper articles and their prior identification as important predictors of environmental protest success by other prior researchers (Ash 2011; Aldrich 2008; Rabe 1994; McGurty 1997). The authors were entirely responsible 
Table 1 Variables

\begin{tabular}{|c|c|}
\hline Violence & $\begin{array}{l}\text { Binary variable, coded yes if there was any kind of physical violence } \\
\text { ranging from beatings to death }\end{array}$ \\
\hline Empowerment & CIRI Index's New Empowerment Rights Index ${ }^{a}$ \\
\hline GDP per capita & World Bank Datab \\
\hline Industry protested against & $\begin{array}{l}\text { Chemical industry, development (construction or land clearing), hydroelec- } \\
\text { tric, logging, mining, nuclear power, nuclear weapons, water, petroleum, } \\
\text { waste disposal, or wind energy }\end{array}$ \\
\hline \multirow[t]{10}{*}{ Geographic region } & Africa \\
\hline & Central Asia \\
\hline & Europe \\
\hline & Latin America \\
\hline & Middle East \\
\hline & North America \\
\hline & Oceania \\
\hline & Southeast Asia \\
\hline & Southern Asia \\
\hline & Taken from United Nations (2012) \\
\hline Project funded with international money & $\begin{array}{l}\text { Coded yes if there was any international funding (e.g., multinational corpo- } \\
\text { rate involvement or international aid) }\end{array}$ \\
\hline Protest duration & Number of years \\
\hline Documented human health hazards of surrounding community & Yes or no \\
\hline Governance & Free, partly free, or not free \\
\hline $\begin{array}{l}\text { Involvement of marginalized groups (defined as economically, } \\
\text { socially, and politically disempowered people) }\end{array}$ & Yes or no \\
\hline
\end{tabular}

for coding the database. We attempted to reduce coding biases by taking a random sample of $25 \%$ of the study cases and performing reciprocal recoding as a reliability test, which resulted in no significant changes to the database based on a general linear model analysis of the changes in variable frequency $(P>0.001)$.

For each protest case, newspaper articles were gleaned for information on potentially important attributes that could play roles in violent outbreaks based on our review of the literature. For each case, we used the rubric in Table 1 to code each case for a range of characteristics that could contribute to violent episodes in environmental protests. Each case contained full attribute records for each potential predictor variable, which restricted our full dataset to 175 cases.

We coded the dependent variable, violence, as a binary variable. If protests were peaceful and authorities used peaceful, lawful means of managing and dispersing the protests, the event was coded as not violent. If there was any physical violence at all against protesters, ranging from roughing up to beatings and murder, the protest was coded as violent.

Regime type was determined using Freedom House's Freedom in the World report, which rates countries as free, partly free, and not free according to a number of measures related to political rights and civil liberties. A number of indices that evaluate democratic freedoms on a country-by-country basis, yet most of them remain highly correlated (Zheng and Liu 2013). We selected the Freedom House Database because of its wide use in scholarship and its long record of historical data, which begin in 1972 (Freedom House 2013) and allowed us to code for democratic freedoms over the exact years of all of the cases included in our study.

To gain a more nuanced measure of state propensity toward repression we also utilized the CIRI Human Rights Dataset. This dataset has been widely used in human right research (Cingranelli and Richards 2010). From this dataset we utilized the empowerment variable that measures government respect for five human rights (movement, speech, worker's rights, political participation, and freedom of religion). The CIRI empowerment index was coded using the mean values over the duration of each protest event. Since the CIRI empowerment index includes measures of freedom of speech, it also helps mitigate our study against the possibility that our measures of violence against protesters are actually measuring a greater willingness of the press to report 
protests/violence rather than greater incidence of protest/violence. While other variables in the CIRI dataset, such as the Physical Integrity Rights Index or Torture, might have been appropriate in theoretical terms, it is likely that the events of violence against protesters collected in our dataset would also have been picked up by the PIRI measure, creating an endogeneity problem. ${ }^{1}$

GDP per capita was measured using World Bank Data (data.worldbank.org) using the same coding methodology as employed in the CIRI empowerment index (i.e. mean values over the duration of each protest event). We also coded the industry that was primarily related to the protest: chemical industry, hydroelectric, logging, mining, nuclear power, petroleum, waste disposal, or wind energy. We had an additional category of development that we coded within the industry variable to cover the handful of cases that could not be attributed to a particular industry and involved large construction projects, usually highways but also bridges, railways, and tourist resorts.

Marginalized groups were coded as positive if the conflict involved any marginalized groups. Marginalized groups were always economically, socially, and politically disempowered people. In most cases they were also ethnic minorities. Geographic region was coded using the United Nations geographic designations (United Nations 2012). International funding was coded as positive if there was evidence of international money involved in the issue under protest (multinational corporations were the most common source; occasionally projects were funded through international funding organizations such as the World Bank). The protest duration was measured as the number of years from the start of the protest to its conclusion. If the conflict continued to the present, the duration of the protest was measured from the start of the protest to 2013, when we collected the data. We also coded for the documented presence of human health hazards in the protest events because the prevalence of human health hazards at a site can serve as a catalyst for grassroots protest (Zheng and Liu 2013; Fagin 2013). Human health hazards were coded as positive if we could find scientific evidence that there was a human health hazard related to the specific conflict event.

\section{Statistical analysis}

All statistical analyses were performed using the $R$ Statistical Language using the party package ( $R$ Development Core Team 2015). We used random forests (RF) (Breiman 2001; R Development Core Team 2015) to identify explanatory protest characteristics that

\footnotetext{
${ }^{1}$ For example, the violence against the Ogoni people in Nigeria as a result of their protests against Shell Oil certainly contributed to Nigeria's high terrorism rankings in the 1990s.
}

differentiated cases where grassroots environmental protests were violently repressed and cases that remained nonviolent throughout. The model incorporated a total of 9 potential predictor variables to differentiate the protest cases into violent or non-violent groups.

The RF classification algorithm is an extension of the classification and regression trees (CART) (Breiman 1984). Classification and regression trees have been widely used to group two or more known classes of observations based on a suite of predictor variables. Classification using CART is achieved through recursive partitioning of the dataset into successively more homogeneous groups. The results are homogeneous subsets of the data based on a series of splits using all of the predictor variables, where the best tree structure is determined by the Gini Index. We used the cforest function in the party package to build our random forest model which using conditional permutation importance. Random forest in this implementation produces multiple CART-like tree classifiers, each based on sub-sampling without replacement (Hothorn et al. 2006). The advantage of using the ctree function in the party package over the original random forest implementation by Breiman (2001) is that it produces unbiased individual trees.

We built a random forest model of 10,000 trees to estimate the predictor variable importance for violent and nonviolent environmental protests. The random number of predictor variables included in each split (mtry) was three which was the square root of the total number of predictor variables as recommended by Breiman (Strobl et al. 2008). We also performed a sensitivity analysis for different numbers of trees and mtry values, but few changes in model output occurred for mtry ranging from 2 to 10 , so the final model used the mtry default value of three and 10,000 trees since computation time was not a hindrance to model construction. Informative predictor variables were determined following Strobl et al. (2008) who indicated that can be considered informative and important if their variable importance value is above the absolute value of the lowest negative-scoring variable. We also estimated various model performance parameters in addition to the standard variable importance measures produced including overall model accuracy, the Kappa Statistic, and the area under the curve (AUC) of the receiver operator characteristic.

\section{Results and discussion}

The following section discusses each of the variables in the study separately and highlights interactive effects. The most powerful predictors of violent repression of environmental protesters were low levels of civil liberties and low economic development. The duration of 
the protest was not a significant predictor of violence, which suggests that violent repression can occur in both intense, short-duration protests, as well as in long, multiyear environmental protests. Industry type was also significant; industries involving natural resource extraction elicited significantly more violence than other industries.

There were complex interactions in the relationships among regime type, presence of marginalized groups, geographic region, and presence of international funding and the use of violence against environmental protesters. Marginalized groups were disproportionately victims of violence around the world, particularly in democratic countries. The most intense cases of violent repression (cases with five or more deaths) all involved extractive industries. Nearly all of them (nine of ten cases) involved international funding, and nine of ten cases also involved marginalized groups.

The random forest model accuracy assessment resulted in a robust model output. The overall model accuracy was $86.8 \%$. The AUC was 0.94 , and the model had a kappa statistic of 0.72 . These figures indicate good overall model performance.

The CIRI empowerment index was by far the best predictor of violent repression against grassroots environmental protests (Fig. 1), which fits our expectations that countries with greater civil rights general have lower incidences of violent repression against protesters. Empowerment was significantly lower $(P<0.0001, t$ test) in countries with violent repression than in countries where violence did not occur. This finding supports the voluminous research using cross-national data, which has shown that protection of basic civil liberties inhibits human rights abuse (Cross 1999; Hill and Rothchild 1992; Keith et al. 2009).

As expected, countries with higher levels of economic development (as quantified by average GDP per capita) repressed citizens less than those with lower levels of development ( $\$ 21,940$ and $\$ 8875$, respectively). This is not to say that violence did not occur in more developed countries, but rather that there was a general trend of less violent repression in more economically affluent geographical locations. Once again, this finding supports numerous studies that have demonstrated the connection between higher levels of GDP per capita and lower levels of governmental repression (Besley and Persson 2011; Weede 1987; Henderson 1991).

The industry type associated with the protest was the third most important factor influencing violent repression. Violent repression was more prevalent in the mining, hydroelectric power, and logging industries (Table 2). Violent repression was most common in the mining industry (15 cases of violence), followed by damming (13 cases of violence), and logging (11 cases of violence)
(Fig. 2; Table 2). In contrast, wind energy, nuclear power, chemical plants, and development protests resulted in largely nonviolent demonstrations. Violent repression of protests that included marginalized groups was most prevalent in extractive industries including logging, petroleum, and mining. These findings support scholars who argue that the subject/object of protest matters (Downey et al. 2010; Tarrow 1998; Tilly 1993). In particular, our results indicate that resource extraction-related projects tend to be significantly more violent than other environment-related projects.

There are several possible reasons for why extractive industries, more than others, tend to be violent. Perhaps, the high level of capital investment raises the stakes for industry and makes them less able to tolerate dissent (Gartner and Regan 1996). Perhaps, extraction industries are more prone to violence for the same reasons that they are prone to corruption - the industry tends to couple monopoly market control without accountability (O'Higgins 2006). Finally, it may be that the isolated geography of resource extraction means that state capacity is less, making violence more possible (Wood 2010; Herreros and Criado 2009). This connection between extractive industries and violence is important because indigenous groups often have contested rights over the land from which the natural resource is being extracted (InterAmerican Commission on Human Rights 2010-2011), and ethnic and economic minorities are disproportionately victims when violence occurs (Downey et al. 2010).

Governmental regime type (free, partly free, or not free) remained an important predictor of violence even when CIRI's Empowerment Index was included, suggesting that democracy exerts a positive effect on the ability of protests to remain nonviolent, independent of the rights granted to citizens. Examining the data more closely, it becomes clear that, consistent with prior research, democratic countries had much higher overall rates of protest as compared with nondemocratic countries (Poe et al. 1999; Weede 1987; Besley and Persson 2011). Democracies had many more cases of peaceful, nonviolent protests (81 cases) than protests that involved violent repression (31 cases). Nondemocratic countries experienced nearly equal rates of nonviolent responses to (32 cases) and violent repression of (31 cases) peaceful environmental protests. There was a strong geographic component to the violence; violent repression was concentrated in Southeast Asia (6 in free countries, 9 in not and partly free countries) and Latin America (7 in free countries, 5 in not and partly free countries) (Fig. 3), while nonviolent responses to protests was predominant in North America and Europe (Fig. 4).

These findings support the literature that suggests that protests overall are more likely in democracies while 


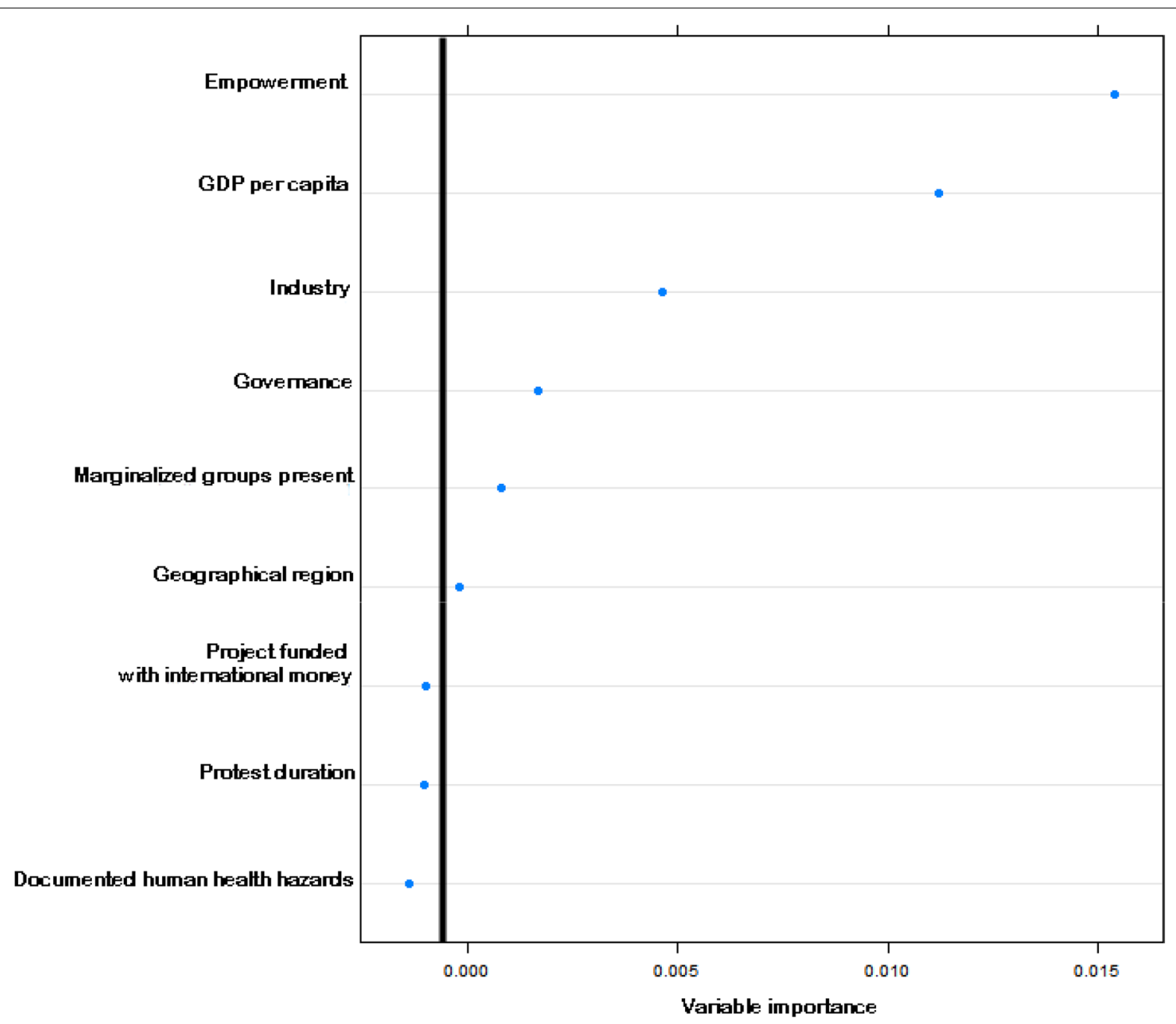

Fig. 1 Factors influencing the violent repression of environmental protests. Figure lists the importance of protest characteristics that differentiated violent repression of grassroots environmental protests from nonviolent responses. The significance cutoff for informative explanatory variables is indicated by the vertical line, which represents the value above the absolute value of the lowest negative-scoring variable. Variable descriptions are provided in Table 1

Table 2 Prevalence of violence and involvement of marginalized groups in grassroots environmental protests by industry

\begin{tabular}{llllllll}
\hline $\begin{array}{l}\text { Percent of protests in industry } \\
\text { involving... }\end{array}$ & \multicolumn{1}{l}{ Industry } & & & & & \\
\cline { 2 - 8 } & Hydro-power & Logging & Mining & Chemical plant & Nuclear power & Petroleum & Waste disposal \\
\hline Violent repression & 52 & 55 & 50 & 22 & 20 & 27 & 19 \\
Marginal groups & 68 & 90 & 71 & 28 & 0 & 33 & 8 \\
Violence against marginalized groups & 62 & 100 & 86 & 25 & 0 & 75 & 0 \\
International funding & 40 & 15 & 64 & 33 & 20 & 67 & 15
\end{tabular}

violent repression of protests is more likely in nondemocratic states and transitioning democracies (Davenport 1999; Franklin 2009; Chenoweth 2013). These findings also concur with scholars who argue that the external context of a protest is more important than the internal characteristics of the protest organization(s) or their tactics in determining the outcome of the protest (Giugni 2004). 


\section{percentage of total violence by industry}

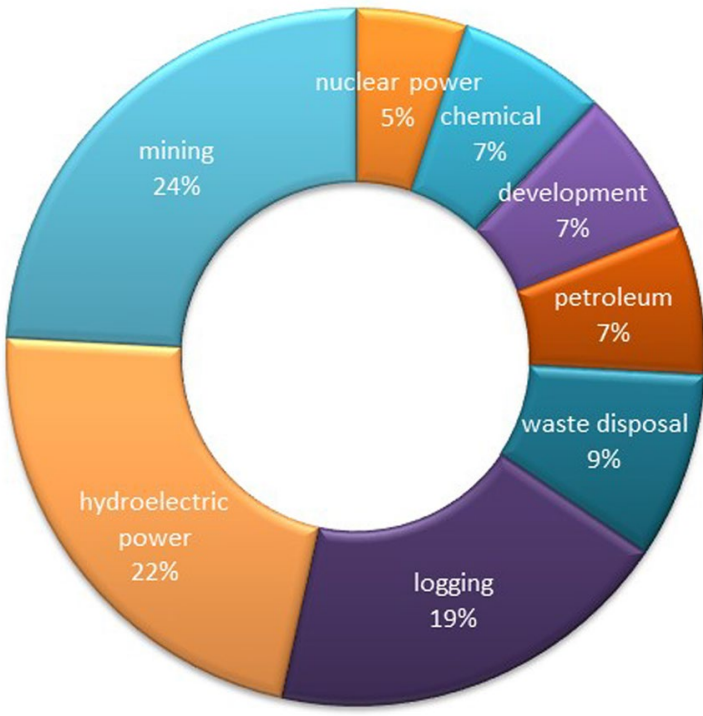

Fig. 2 Violence by industry type

Our findings do not support research arguing that violent tactics by protesters play a significant role in eliciting violent responses from authorities (Porta and Piazza
2007). The large majority (72 \%) of violence in the dataset was directed against peaceful protesters who did not respond violently in any way. A minority (14\%) of protests involved violence on both sides (violence against the protesters was significantly larger than the reverse). A tiny minority-only five cases in the whole dataset-were situations where the protesters acted violently toward nonviolent opponents. There may be other context where violent tactics are causally related to violent repression, but in the cases of grassroots environmental protests, the causes of repression appear to have much more to do with the socio-economic context of the conflict and the identity of the aggrieved than protester tactics.

Marginalized groups figured prevalently in environmental protest overall and in protests with violence against activists in particular. Just under half of our cases worldwide involved marginalized groups (45\%). Consistent with the voluminous environmental justice literature, marginal communities were disproportionately targeted as sites for environmentally damaging activities (Bernauer et al. 2013; Homer-Dixon 1994; Koopmans and Rucht 2002). Marginal groups were involved in one-third of the cases of nonviolent responses to protest; a high figure given that the groups usually represented a small fraction of the country's general population. When examining the involvement

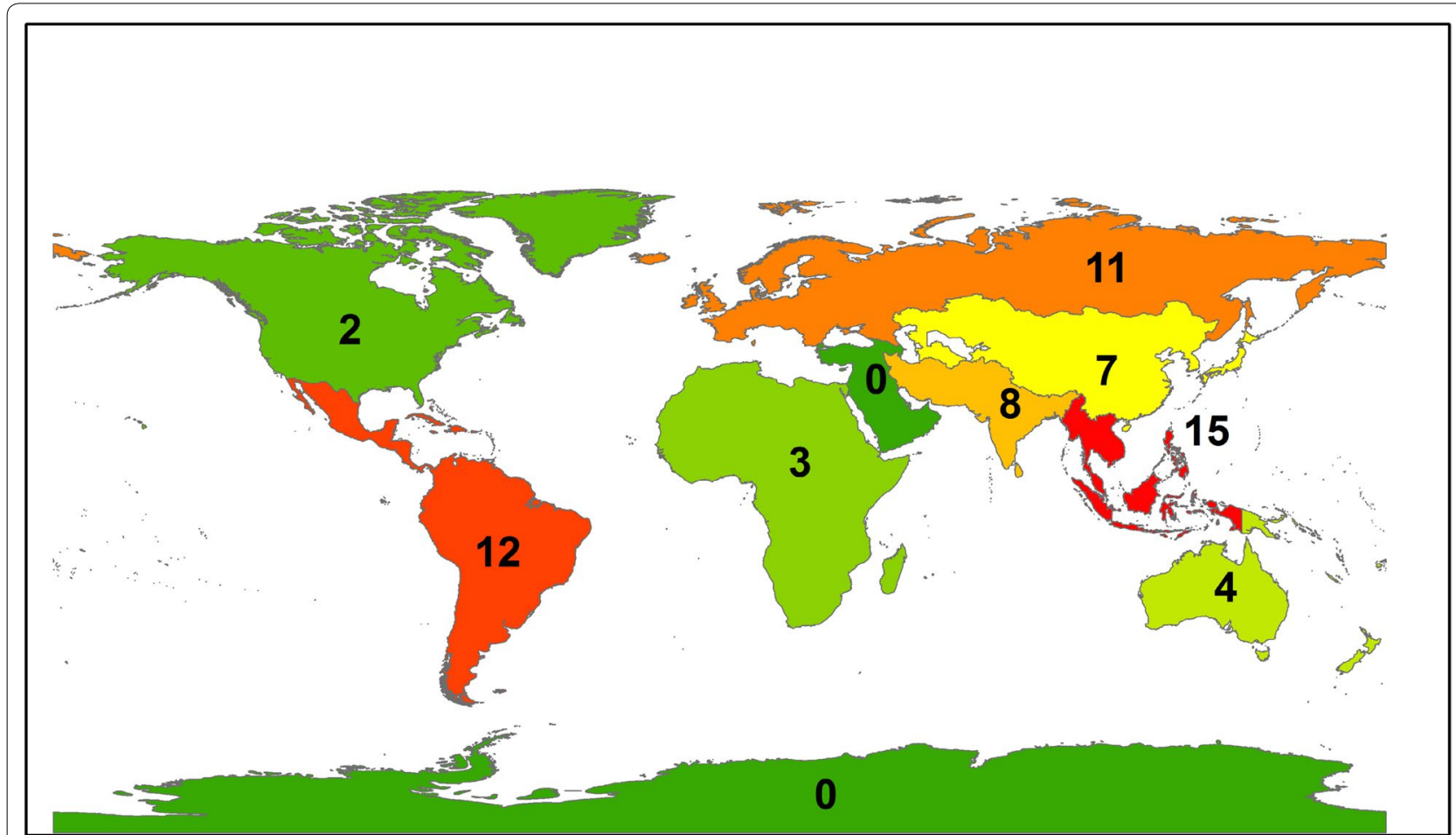

Fig. 3 Violent repression of grassroots environmental protests from 1965 to $1980(n=175)$. Geographical regions are categorized according to designations by the United Nations 


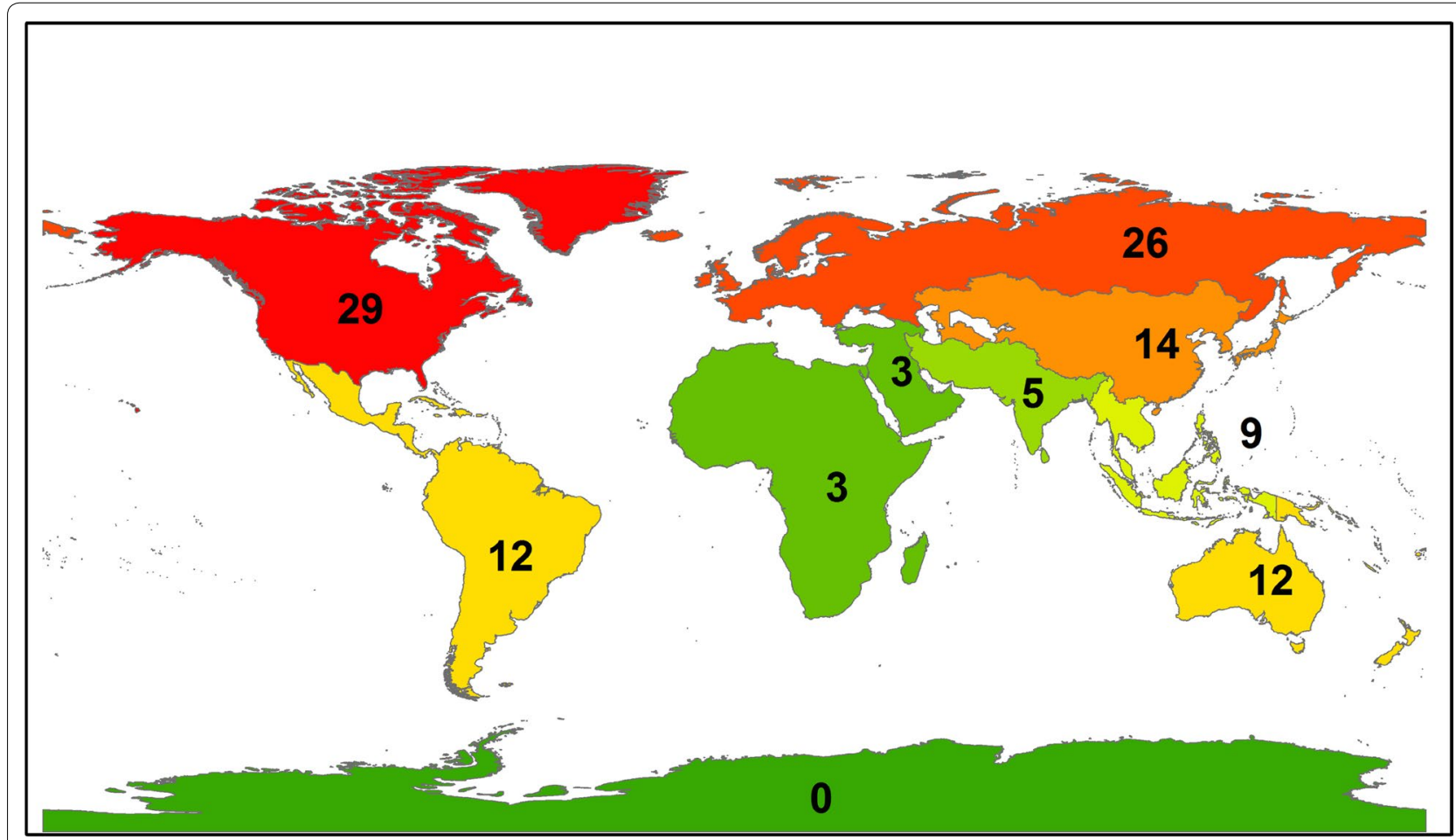

Fig. 4 Nonviolent response to grassroots environmental protests from 1965 to 1980 ( $n=175)$. Geographical regions are categorized according to designations by the United Nations

of marginalized groups in protests that were violently repressed, the figure rises to $60 \%$.

Most troubling was the combined effect of industry and marginalized victims. A large majority of the violent repression of environmental protests in the extractive industries of logging, mining, and petroleum involved marginalized groups $(100,86$, and $75 \%$, respectively). Violent repression of dam-related protests also targeted marginal communities, and $68 \%$ of these cases involved marginal groups.

The interaction between regime type and violence against marginal groups was perhaps opposite from what might have been expected by the literature, which suggests that marginal groups are more vulnerable in nondemocratic countries than in democratic ones (Downey et al. 2010; Adeola 2000; Franklin 2009). Although democratic countries overall experienced lower rates of violent repression of protests, those cases where violent repression did occur nearly always targeted marginalized groups (Fig. 5). In the democracies of North America and Oceania in particular, $100 \%$ of violent repression of peaceful environmental protests involved marginalized groups.

This finding refines and complicates the environmental justice literature that holds that marginal groups in poor, nondemocratic countries are the most vulnerable to violent repression (Adeola 2000; Salehyan et al. 2012). Our findings support the vulnerability of marginalized groups in poor and nondemocratic countries-three of the four cases where death tolls exceeded one hundred people occurred in nondemocratic countries; all of them related to extractive industries funded with international funding. However, our findings also suggest that violence against marginal groups engaging in environmental protests is a very serious problem for all countries, irrespective of political regime type. While only one-third of the cases of violence in nondemocratic countries involved marginalized groups (6 of 18 cases), $63 \%$ of violence in free countries involved marginalized groups (17 of 27 cases), and $76 \%$ of violence in partly free countries involved marginalized groups (Fig. 5).

Although international funding was not statistically significant in our model, it was strongly associated with the most extreme cases of violence. In the dataset there were only ten cases where the violence involved more than five deaths, making them relatively rare events, which are difficult to analyze statistically (King and Zeng 2001). In all ten of those cases local people were protesting the extraction of natural resources, and in all but one of the cases international money was supporting the project (Table 3). Furthermore, once again marginalized communities were disproportionately targeted; in nine of 


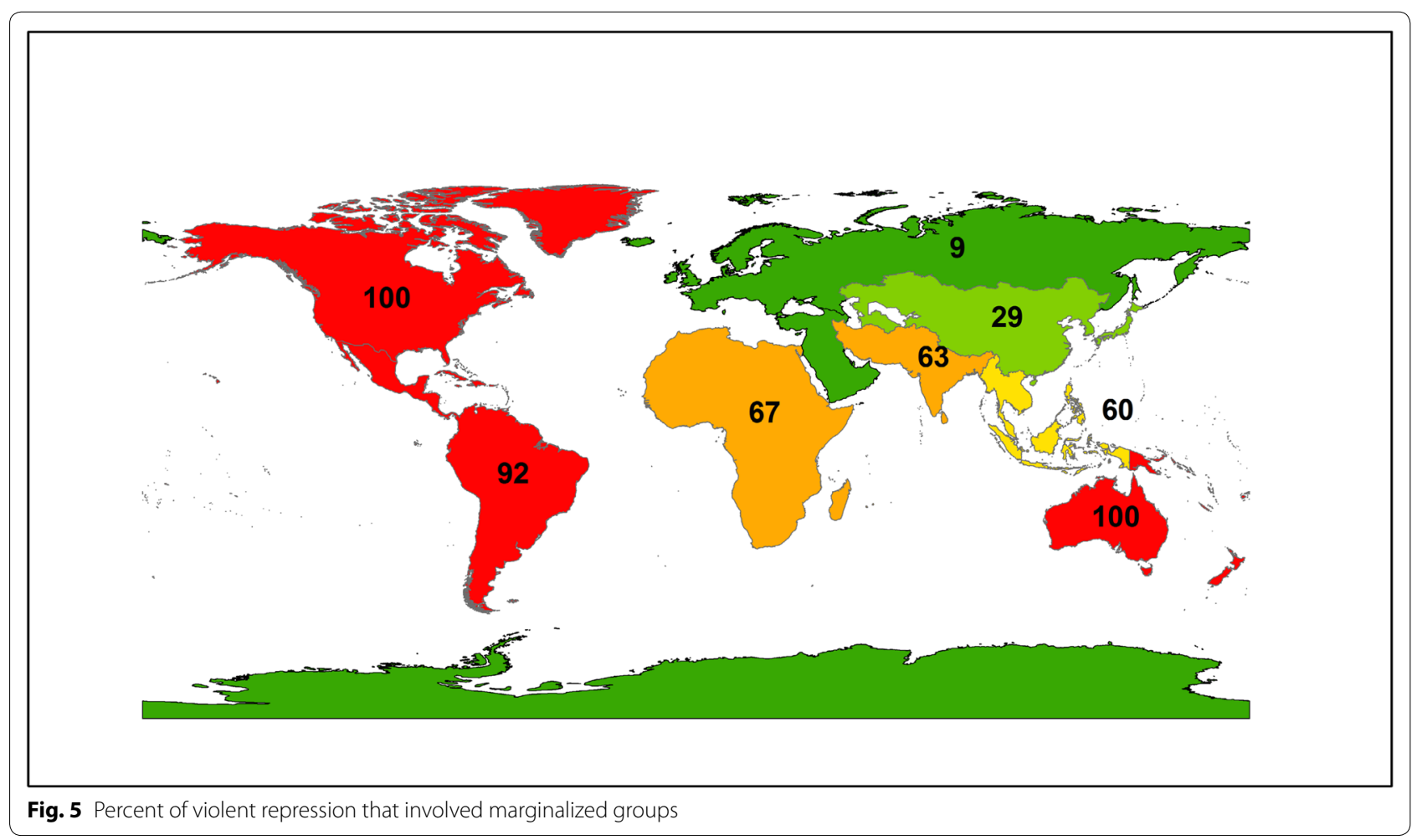

the ten cases of extreme violence victims came from marginalized groups.

In this small subset of cases, where violence resulted in the death of between five and five thousand individuals, violence was extensive and culpability was complex. In most cases, the local government or its agents were the direct perpetuators of the violence, but the disputed project involved significant international funding that influenced the decision to repress the protesters with violence. Some of these cases are well known and well-researched, such as the massacre of Ogoni people in Nigeria in the early 1990 s as their protest against petroleum projects in their area expanded into broader demands for selfdetermination. Other cases that resulted in intermediate numbers of deaths are less well known, such as the 1990 'Christmas Massacre' in Bolivia where 11 miners were killed when government forces gave the miner's union occupying a tin mine a scant fifteen-minute warning before they open fired.

Although not statistically significant, international funding was disproportionately found in the cases of violent repression across the dataset (it was present in $29 \%$ of the nonviolent cases but $45 \%$ of cases where the protests were violently repressed). Furthermore, when international funding was coupled with an extractive industry, the chances of violence rose dramatically. International funding was involved in a large majority of the projects that elicited violence in the mining (78 \%) and petroleum (100\%) industries. Of the industries that spurred primarily nonviolent responses to protests, most of the isolated incidents of violent repression that did occur in these industries also involved international funding: wind energy (100\%), chemical plants (50\%), development projects (50\%), and waste disposal (40\%). These findings support scholarship that argues that extractive industries funded by international capital are prone to violence (Downey et al. 2010). They also suggest that international funding may increase the propensity of violence even in industries that are not extractive and not ordinarily prone to violence.

\section{Conclusions}

This study represents the first comprehensive worldwide assessment of violent repression of grassroots environmental protests. Our findings demonstrate that violence against peaceful environmental protesters is not just a problem in poor, nondemocratic countries. Violence against peaceful environmental protesters occurred most frequently when communities that included marginalized groups protested natural resource extraction in their community.

Previous studies of environmental justice have frequently argued that enhancing the socio-economic standing of victims and potential victims is the best way to combat 
Table 3 Characteristics of protest cases where more than five deaths occurred as a result of the protest

\begin{tabular}{|c|c|c|c|c|c|c|c|c|c|c|}
\hline Protest case & Deaths & $\begin{array}{l}\text { International } \\
\text { funding }\end{array}$ & Country & Issue & Industry & $\begin{array}{l}\text { Geographic } \\
\text { region }\end{array}$ & $\begin{array}{l}\text { Marginalized } \\
\text { groups }\end{array}$ & $\begin{array}{l}\text { Start } \\
\text { year }\end{array}$ & $\begin{array}{l}\text { Duration } \\
\text { (years) }\end{array}$ & $\begin{array}{l}\text { Regime } \\
\text { type }\end{array}$ \\
\hline $\begin{array}{l}\text { Belo Monte } \\
\text { Dam }\end{array}$ & 6 & $\begin{array}{c}\text { Alcoa, Vale } \\
\text { (mining) }\end{array}$ & Brazil & Conservation & $\begin{array}{l}\text { Hydroelectric } \\
\text { power }\end{array}$ & Latin America & Yes & 1987 & 25 & Partly free \\
\hline $\begin{array}{l}\text { PT Inti } \\
\text { Indorayon } \\
\text { Utama Indo- } \\
\text { nesian Paper } \\
\text { Mill }\end{array}$ & 6 & No & Indonesia & Pollution & Paper mill & $\begin{array}{l}\text { Southeast } \\
\text { Asia }\end{array}$ & No & 1993 & 6 & Not free \\
\hline $\begin{array}{l}\text { Tia Maria Cop- } \\
\text { per Mine }\end{array}$ & 6 & $\begin{array}{l}\text { Southern } \\
\text { Copper }\end{array}$ & Peru & Pollution & Mining & Latin America & Yes & 2010 & 3 & Free \\
\hline $\begin{array}{l}\text { Andean } \\
\text { Amaya- } \\
\text { pampa Mine }\end{array}$ & 11 & Vista Gold & Bolivia & Pollution & Mining & Latin America & Yes & 1996 & $<1$ & Free \\
\hline $\begin{array}{l}\text { BHP Billiton } \\
\text { Nickel Mine } \\
\text { in Sibuyan } \\
\text { Island }\end{array}$ & 20 & BHP Billiton & Philippines & Conservation & Mining & $\begin{array}{l}\text { Southeast } \\
\text { Asia }\end{array}$ & Yes & 2005 & 8 & Partly free \\
\hline Xstrata Mine & 24 & Xstrata & Peru & Conservation & Mining & Latin America & Yes & 1985 & 28 & Free \\
\hline $\begin{array}{l}\text { Occidental } \\
\text { Petroleum } \\
\text { Company } \\
\text { Drilling }\end{array}$ & 30 & $\begin{array}{l}\text { Occidental } \\
\text { Petroleum }\end{array}$ & Colombia & Conservation & Petroleum & Latin America & Yes & 1992 & 13 & Partly free \\
\hline $\begin{array}{l}\text { Shell Oil Ogoni } \\
\text { Protest }\end{array}$ & 2000 & Shell Oil & Nigeria & Pollution & Petroleum & Africa & Yes & 1992 & 21 & Not free \\
\hline $\begin{array}{l}\text { Chixoy Dam in } \\
\text { Rio Negro }\end{array}$ & 5000 & $\begin{array}{l}\text { World Bank } \\
\text { IADB }\end{array}$ & Guatemala & Conservation & $\begin{array}{l}\text { Hydroelectric } \\
\text { power }\end{array}$ & Latin America & Yes & 1982 & 31 & Not free \\
\hline
\end{tabular}

Nine of the ten cases had funding with international money and nine of the ten cases also involved marginalized groups

violence (Roberts and Ash 2009; McGurty 1997; Aldrich 2008; Rabe 1994; Giugni 2004; Ash et al. 2009). Our findings support this common recommendation: disrespect of fundamental human rights and low per capita income were the two most significant factors increasing the likelihood that any given grassroots environmental protest would be violently repressed. However, these two policy recommendations are vague, broad, and difficult to implement.

Our findings that victims of violence are most commonly found in communities containing marginalized groups and the frequent involvement of international funding in cases of violent repression enables us to refine our policy recommendations. We recommend that sustainable development initiatives targeting local communities be built into the project plans for internationally funded development projects, especially when those projects are related to extractive industries. These initiatives would involve integration of local communities into the governance structures present at the site of the project, building economic frameworks that create jobs and economic opportunities for the community during and after the project takes place, and extensive plans for environmental mitigation of any harm caused by the project. These locally focused sustainable development initiatives should be created for all projects, not just for those located in poor countries.
The process of working with local communities to ensure that the development project minimizes its effects on the local population and mitigates its environmental damage, will help create the 'social license' necessary for the development to proceed smoothly (Gunningham et al. 2004; Prno and Slocombe 2012). Creating governance structures that engage local stakeholders early and establish clear grievance procedures can reduce the likelihood that local community members will protest a given project and also reduce the likelihood of violence if protests do emerge (Holliday and Yep 2005; Lemos and Agrawal 2006). Industry now has many decades of experience incorporating sustainable development initiatives into large-scale development projects as a component of their risk management and CSR initiatives (Breshears et al. 2005; Castka and Balzarova 2008); http://www. commdev.org). Furthermore, international governmental organizations such as the United Nations and the World Bank have developed comprehensive frameworks for incorporating sustainable development practices into both business development models as well as local and national regulatory frameworks (Ruggie 2008, 2011). The International Finance Corporation's CommDev (Commdev.org) website has an extensive repository of practical information related to incorporating sustainable development into project plans, including a Financial Valuation 
Tool, which helps firms and investors estimate the financial return on site-specific sustainability investments. These industry and international organization-developed tools also offer guidelines for appropriate ways to compensate individuals and communities who are displaced by large-scale projects, which is another important element in the efforts to eliminate violence related to these projects.

Responsible corporations and industries are already incorporating local sustainability initiatives into their business models. Industrial groups need to become more active in disseminating the best practice models that they have developed, increasing the pressure on non-compliant firms to raise their standards. Governments, both local and national, should support industry efforts by supporting the projects of corporations that incorporate local sustainable development into their project plans and rejecting projects that do not. Nonprofit and advocacy organizations concerned about human rights and environmental sustainability as well can help support local sustainability initiatives in communities that host extractive industry development projects. Local sustainability should be actively incorporated into large-scale development projects, especially when those projects are taking place in communities that contain marginalized people. Promoting local sustainability as part of development projects will not only enhance environmental outcomes, it will also help prevent tragic human rights abuses that have, unfortunately, been a common outgrowth of extractive industry projects around the world.

\section{Authors' contributions}

HP read the articles, coded the database, ran the statistical analyses, and wrote up the methods and analysis sections of the paper. MAH also helped code the database, synthesized results, and co-wrote the paper. Both authors read and approved the final manuscript.

\section{Author details}

${ }^{1}$ College of the Environment, Wesleyan University, 284 High St., Middletown, CT 06451, USA. ${ }^{2}$ Government Department, Wesleyan University, Middletown, CT 06451, USA.

\section{Acknowledgements}

The authors would like to thank Barry Chernoff and Wesleyan University's College of the Environment think tank for fruitful conversations that greatly contributed to this manuscript.

\section{Competing interests}

Both authors declare that they have no competing interests.

Received: 19 November 2015 Accepted: 12 February 2016

Published online: 29 February 2016

\section{References}

Adeola FO (2000) Cross-national environmental injustice and human rights issues a review of evidence in the developing world. Am Behav Sci 43(4):686-706
Aldrich DP (2008) Site fights: divisive facilities and civil society in Japan and the West/Daniel P. Aldrich. Vol Accessed from http://nla.gov.au/nla.catvn4320416. Cornell University Press, Ithaca

Ash K (2011) A game-theoretic model for protest in the context of post-communism. Communist Post-Communist Stud 44(1):1-15

Ash M, Boyce JK, Chang G, Pastor M, Scoggins J, Tran J (2009) Justice in the air: tracking toxic pollution from America's industries and companies to our states, cities and neighborhoods. Political Economy Research Institute, Amherst, MA

Barranco J, Wisler D (1999) Validity and systematicity of newspaper data in event analysis. Eur Sociol Rev 15(3):301-322

Bernauer T, Böhmelt T, Koubi V (2012) Environmental changes and violent conflict. Environ Res Lett 7(1):015601

Bernauer T, Böhmelt T, Koubi V (2013) Is there a democracy-civil society paradox in global environmental governance? Glob Environ Polit 13(1):88-107

Besley T, Persson T (2011) The logic of political violence. Q J Econ 126(3):1411-1445

Blanton R, Blanton SL (2009) Virtuous or vicious cycle? Human rights, trade, and development. In: Reuveny R, Thompson WR (eds) North and South in the world political economy (Chap. 5). Wiley, pp 91-103

Bond D, Bond J, Oh C, Jenkins JC, Taylor CL (2003) Integrated data for events analysis (IDEA): an event typology for automated events data development. J Peace Res 40(6):733-745

Box-Steffensmeier JM, Zorn C (2002) Duration models for repeated events. J Polit 64(04):1069-1094

Box-Steffensmeier JM, Reiter D, Zorn C (2003) Nonproportional hazards and event history analysis in international relations. J Conflict Resolut 47(1):33-53

Breiman L (1984) Classification and regression trees. The Wadsworth statistics/ probability series. Wadsworth International Group, Belmont, CA

Breiman L (2001) Random forests. Mach Learn 45(1):5-32

Breshears DD, Cobb NS, Rich PM, Price KP, Allen CD, Balice RG, Romme WH, Kastens JH, Floyd ML, Belnap J, Anderson JJ, Myers OB, Meyer CW (2005) Regional vegetation die-off in response to global-change-type drought. Proc Natl Acad Sci USA 102(42):15144-15148. doi:10.1073/ pnas.0505734102

Castka P, Balzarova MA (2008) Social responsibility standardization: guidance or reinforcement through certification? Human Syst Manag 27(3):231

Chenoweth E (2013) Terrorism and democracy. Annu Rev Polit Sci 16:355-378

Cingranelli DL, Richards DL (2010) The Cingranelli and Richards (CIRI) human rights data project. Human Rights Q 32(2):401-424

Cross FB (1999) The relevance of law in human rights protection. Int Rev Law Econ 19(1):87-98

Dalton RJ, Recchia S, Rohrschneider R (2003) The environmental movement and the modes of political action. Comp Polit Stud 36(7):743-771

Davenport C (1999) Human rights and the democratic proposition. J Conflict Resolut 43(1):92-116

Downey L, Bonds E, Clark K (2010) Natural resource extraction, armed violence, and environmental degradation. Organ Environ 23(4):417-445

Earl J, Martin A, McCarthy JD, Soule SA (2004) The use of newspaper data in the study of collective action. Ann Rev Soc 30:65-80. doi:10.2307/29737685

Fagin D (2013) Toms river: a story of science and salvation. Random House LLC, New York

Fillieule O, Jiménez M (2003) Appendix A: the methodology of protest event analysis and the media politics of reporting environmental protest events. In: Rootes C (ed) Environmental protest in Western Europe. Oxford University Press, Oxford, pp 258-279

Franklin JC (2009) Contentious challenges and government responses in Latin America. Polit Res Q 62(4):700-714

Gartner SS, Regan PM (1996) Threat and repression: the non-linear relationship between government and opposition violence. J Peace Res 33(3):273-287

Giugni M (2004) Social protest and policy change: ecology, antinuclear, and peace movements in comparative perspective. Rowman \& Littlefield, Lanham, MD

Gunningham N, Kagan RA, Thornton D (2004) Social license and environmental protection: why businesses go beyond compliance. Law Soc Inq 29(2):307-341 
Haddad MA (2014) Paradoxes of democratization. In: Routledge handbook of environment and society in Asia, p 86

Henderson CW (1991) Conditions affecting the use of political repression. J Conflict Resolut 35(1):120-142

Herreros F, Criado H (2009) Pre-emptive or arbitrary: two forms of lethal violence in a civil war. J Conflict Resolut 53(3):419-445

Hill S, Rothchild D (1992) The impact of regime on the diffusion of political conflict. In: Midlarksy M (ed) The internationalization of communal strife. Routledge, London, pp 189-207

Holliday I, Yep R (2005) E-government in China. Public Adm Dev 25(3):239-249

Homer-Dixon TF (1994) Environmental scarcities and violent conflict: evidence from cases. Int Secur 19(1):5-40

Hothorn T, Bühlmann P, Dudoit S, Molinaro A, Van Der Laan MJ (2006) Survival ensembles. Biostatistics 7(3):355-373

House F (2013) Freedom in the world 2013. Retrieved 1 May 2013

Inter-American Commission on Human Rights (2010-2011) Indigenous and tribal peoples'rights over their ancestral lands and natural resources: norms and jurispurdence of the Inter-American Human Rights System. Am Indian Law Rev 35(2):263-496

Keith LC, Tate CN, Poe SC (2009) Is the law a mere parchment barrier to human rights abuse? J Polit 71(02):644-660

King G, Zeng L (2001) Logistic regression in rare events data. Polit Anal 9(2):137-163

Koopmans R, Rucht D (2002) Protest event analysis. Methods Soc Mov Res 16:231-259

Lemos MC, Agrawal A (2006) Environmental governance. Annu Rev Environ Resour 31:297-325

McGurty EM (1997) From NIMBY to civil rights: the origins of the environmental justice movement. Environ Hist 2(3):301-323. doi:10.2307/3985352

O'Higgins E (2006) Corruption, underdevelopment, and extractive resource industries: addressing the vicious cycle. Bus Ethics Q 16(2):235-254

Ortiz DG, Myers DJ, Walls EN, Diaz M-ED (2005) Where do we stand with newspaper data? Mobili Int Q 10(3):397-419

Poe SC, Tate CN, Keith LC (1999) Repression of the human right to personal integrity revisited: a global cross-national study covering the years 1976-1993. Int Stud Q 43(2):291-313

Porta DD, Piazza G (2007) Local contention, global framing: the protest campaigns against the TAV in Val di Susa and the bridge on the Messina Straits. Environ Polit 16(5):864-882
Prno J, Slocombe DS (2012) Exploring the origins of 'social license to operate'in the mining sector: perspectives from governance and sustainability theories. Resour Policy 37(3):346-357

R Development Core Team (2015) A language and environment for statistical computing. R Foundation for Statistical Computing, Vienna

Rabe BG (1994) Beyond nimby. Brookings Institution, Washington DC

Roberts A, Ash TG (2009) Civil resistance and power politics: the experience of non-violent action from Gandhi to the present. Oxford University Press, Oxford

Ruggie J (2008) Protect, respect and remedy: a framework for business and human rights. Innovations 3(2):189-212

Ruggie J (2011) Report of the Special Representative of the Secretary-General on the issue of human rights and transnational corporations and other business enterprises. Neth Q Human Rights 29:224

Salehyan I, Hendrix CS, Hamner J, Case C, Linebarger C, Stull E, Williams J (2012) Social conflict in Africa: a new database. Int Interact 38(4):503-511

Snow DA, Soule SA, Kriesi H (2008) The Blackwell companion to social movements. Wiley, New York

Strobl C, Boulesteix A-L, Kneib T, Augustin T, Zeileis A (2008) Conditional variable importance for random forests. BMC Bioinformatics 9(1):307

Tarrow S (1998) Fishnets, internets and catnets: globization and transnational collective action. In: Hanagan M, Moch L, TeBrake W (eds) The past and future of collective action. University of Minnesota Press, Minneapolis, pp 228-244

Tilly C (1993) Social movements as historically specific clusters of political performances. Berkeley J Sociol 38:1-30. doi:10.2307/41035464 (ArticleType: research-article/Full publication date: 1993-1994/Copyright $\odot 1993$ Regents of the University of California)

United Nations (2012) United Nations Statistics Division

Weede $E$ (1987) Some new evidence on correlates of political violence: income inequality, regime repressiveness, and economic development. Eur Sociol Rev 3(2):97-108

Wood R (2010) Rebel capability and strategic violence against civilians. J Peace Res 47(5):601-614

Zheng C, Liu J (2013) China's "Love Canal" moment? Science (New York, NY) 340(6134):810

\section{Submit your manuscript to a SpringerOpen ${ }^{\circ}$ journal and benefit from:}

- Convenient online submission

- Rigorous peer review

- Immediate publication on acceptance

- Open access: articles freely available online

- High visibility within the field

- Retaining the copyright to your article

Submit your next manuscript at $>$ springeropen.com 